\title{
Relationship between Principals' Transformational Leadership Style and Secondary School Students' Academic Performance in Kenya Certificate of Secondary Education in Bomet County, Kenya
}

\author{
Kipkoech Kitur ${ }^{1, *}$, Jepkemboi Choge ${ }^{2}$, Edward Tanui ${ }^{3}$ \\ ${ }^{1}$ Maasai Mara University, Kenya \\ ${ }^{2}$ School of Education, Bomet University College, Kenya \\ ${ }^{3}$ Department of Curriculum, Instruction and Education Management, Maasai Mara University, Kenya
}

Received November 1, 2019; Revised December 18, 2019; Accepted December 30, 2019

Copyright $\bigcirc 2020$ by authors, all rights reserved. Authors agree that this article remains permanently open access under the terms of the Creative Commons Attribution License 4.0 International License

\begin{abstract}
Leadership style is an important aspect in students' academic performance in schools. Transformational leadership style is associated with the students' academic achievement in KCSE. The study sought to establish the relationship between idealized influence of principals' transformational leadership style and students' academic performance in KCSE in Bomet County in Kenya. The descriptive survey design was used for this study whose target population comprised of 130 secondary schools and five Quality Assurance and Standards Officers in Bomet County. Stratified random sampling procedure was adopted to sample out schools as boys', girls' and mixed schools; then Slovin's formula was used to obtain a total of 108 schools. While purposive sampling procedure was applied to choose one Director of Studies from each 108 schools selected and five Quality Assurance and Standards Officers from the five sub-counties in Bomet County. A total sample of 118 respondents from 108 secondary schools and the five sub-counties participated in the study. When collecting the data, instruments used were Director of Studies' questionnaires, Quality Assurance and Standards Officers' interview guides, school and Bomet County Director of Education KCSE records. Chi-square test was adopted to establish the relationship between principals' idealized influence and academic performance and the results showed that principals' idealized influence had a strong significant relationship with students' academic performance in KCSE. Thus, idealized influence characteristics are most effective in promoting students' academic achievement. The study recommends that the
\end{abstract}

idealized influence should be adopted and displayed by principals in order to improve academic performance in KCSE examinations.

Keywords Idealized Influence Transformational Leadership and Students' Academic Performance

\section{Introduction}

\subsection{Background of the Study}

Leadership is the most effective when leaders choose more effective styles like transformational leadership (Germano, 2010). It is easy to practice idealize influence of transformational leadership, and is the best style of leadership in all situations. The leader, who displays high level of experience in both the public and private sector, is highly educated, positive, optimistic, and has understanding of strong educational practices, desire high expectations and standards (Hughes, 2014). Idealized influence describes leaders that serve as role models for their followers, allow them to identify with a shared organizational vision, and provide a sense of meaning and achievement (KEMI, 2014). It involves school principal leading by example, mentoring, having high expectation, having a best-practices emphasis, holding students and teachers accountable among others (Hauserman \& Stick, 2013).

Globally, effective schools are the key to improved 
performance particularly of students in all aspects (Kinyua, 2015). School administrators can manage diversity in school in a more effective manner as a result of adopting especially transformational leadership behaviours (Veysel, 2014). Since 1980s, transformational leadership is recognized as one of the current approaches to leadership that has been the focus of much research (Achieng, 2013). In Malaysia, $60 \%$ of the Collegial Leadership (friendly environment) found within a school is related to the transformational leadership style of the principal (Khademfar \& Idris, 2012). School principals demonstrate a high level of characteristics of transformational leadership in terms of inspirational motivation, individualized consideration, idealized influence, and intellectual stimulation behaviours. Prospective principals should be trained, as transformational leaders during their college training and the current principals should be supported to be transformational leaders with in-service training prepared by university-ministry cooperation in Turkey (Balyer, 2012). In Zanzibar, a participant pointed out that there is a rapid change in education and quality teaching comes from good leaders. The dynamic in education require preparation and dynamic principals. Also mentoring and coaching were highlighted as useful skills and head teachers need training in mentoring so they can learn how to support their teachers rather than use harsh language (MoEVT's, 2013). World Bank studies carried in Zambia, Uganda and Kenya showed quite often highly trained teachers led in being absent from school for no apparent reasons and one of the reasons is poor supervision (Kigotho, 2011). In Kenya, teacher education and training should be structured to incorporate development of leadership knowledge and skills (Choge, 2015). The training institutions should incorporate different models of leadership such as transformational leadership style based on Fielder's contingency theory (Mwendwa, 2012). There is need for retraining of practicing principals in transformational leadership so as to match the changing trends in the modern society (Nderitu, 2012).

Principals' overall responsibility is to facilitate teaching and learning designed to enhance student achievement (Cooper, 2011). School leaders must mould the culture of the school in order to create an environment conducive to learning (Moffitt, 2007). The leadership dimension that is most strongly associated with positive student outcomes is that of promoting and participating in teacher learning and development (Robinson, Lioyd \& Rowe, 2008). The leadership style has to be exercised by principals always for quality results in the school. Transformational leadership is crucial (Ogalo, 2013). It is a definite advantage for everyone involved in the school (Cashin, 2000). And it is widely believed to be the most effective leadership style (Jess, 2014). Transformational leaders are perceived to have facilitated positive changes such as increased student achievement (Denmark, 2012).

The four transformational leadership behaviours are more effective than constructive transactional leadership (Avolia, 2010). Transformational leadership has grown in its recognition and popularity because of its seemingly ubiquitous application. It involves four factors: inspirational motivation, intellectual stimulation, idealized influence, and individualized consideration (Hughes, 2014). Such behaviours are positively related to better performance (Balyer, 2012). Transformational leadership practices are significant and essential in promoting high academic performance by encouraging the participation of all stakeholders in focusing on improving student learning through idealized influence (Jebii, 2019). The purpose of No Child Left Behind was to narrow and perhaps even close the achievement gap in America (Nowlin, 2015). Americans students are performing far below most other developed nations on triennial international test (Bidwell, 2013). Some schools require a head teacher who will lift the schools from a state of complacency and failure to a state of dignity and high performance in Botswana (Oyetunji, 2006). In Nigeria, there was a marked difference in the performance of students in urban and rural schools in Senior Secondary school Examination with impressive scores obtained in urban schools. Government should always be conscious of the implication of its policies and position on schooling and the multiplier effect on academic performance of students and teachers productivity (Adepoju \& Oluchukwu, 2011). It was established that the nature of secondary school head teacher's training contributed to either poor or good leadership and hence school performance in Uganda (Nsubuga, 2008).

In Kenya, it is non-disputable that success or failure of any organization depends on its leadership. And school efficiency that is measured by factors such as students' academic performance and discipline (Nderitu, 2012). Head teachers with high rating leadership skills can promote good academic performance (Awino, Kiplangat and Onderi, 2014). Although the government has even invested a lot of funds in education, it is sad that many schools do not provide teaching and learning in the most efficient way (Kimani et al., 2013). This raises concerns of parents, leaders and scholars (Nyongesa, 2014). Therefore, public pressure on school administrators and teachers to improve academic performance has led to schools coming up with various performance improvement strategies (Nyagosia, 2011). The current Education Sector Plan (2013-2018) prioritizes the enhancement of learner outcomes through addressing issues related to quality (Ministry of Education, 2014). The current teaching practices in Kenya focuses on producing "A" grade learners and those societal settings that attach a lot of value to test score (Kaume \& Mwinzi, 2018). And for effective learning to take place, it needs prepared school leadership (Gatobu, 2019).

Learning outcomes at the secondary school level are still weak, with 70 percent of KCSE candidates failing to achieve $\mathrm{C}+$, which is the minimum requirement for 
admission to university as depicted by the 2010-2014 KCSE results (Kaimenyi, 2014). Quality education is associated with getting quality grades by students in KCSE examinations. The principal's leadership styles often have massive influence on the KCSE performance in schools (Koskei, Tanui \& Rono, 2018). The grade attained by the learner in KCSE becomes a significant turning point in its life and future career (Nkaiwuatei, 2013). For the five years, 2010-2014 KCSE examinations, about 70\% of the candidates have consistently scored between mean grades of $\mathrm{C}$ to $\mathrm{D}$ - which qualifies them for admission to middle level colleges. However, about $2 \%$ of candidates have been scoring E over the period. Transition to university is below 40 percent (Kaimenyi, 2014). Nationally, from the year 2012 to 2015 KCSE Examinations, those who attained grade $\mathrm{D}$ to $\mathrm{E}$ have been consistently high, $66.528 \%$. Over the same period, the average mean score was 5.286, mean grade of C-(Kenya National Bureau of Statistics, 2017).

In Bomet County, Kenya, there was significant discrepancy in academic performance among the schools of similar category. During the 2010-2014 K.C.S.E., the average range mean score disparity was 6.20 and 5.00 points for the county and sub-county schools respectively. During the five years, best mean grade has increased to $\mathrm{B}+$ from B-, and the least has stagnated at grade D for the county schools. Respectively for the sub-county schools was from grades C+ to B- and D- to D (County Director of Education, 2015). Hence, there was need to ascertain the role of principals' leadership and much more transformational leadership.

Statistics in Bomet showed that based on a minimum university entry score of grade $\mathrm{C}+$ and above, indicated that students joining university from the county are few. Hence, many of them lose opportunities for higher education, training and job placement (Makau \& Tanui, 2014). Thus, this needed to be determined. Various studies have been done to explain this phenomenon but its relationship between transformational leadership has not yet been done. Thus, the study was expected to determine the relationship between the idealized influence principals' transformational leadership and secondary school students' academic performance in KCSE examination in Bomet County.

\subsection{Statement of the Problem}

Transformational leadership style is an important aspect in students' academic achievement in schools. In Kenya, the principals who exhibit the transformational leadership behaviours results in a measurable influence in the KCSE performance. Principals are held accountable for quality education which is associated with getting quality grades by students in KCSE examinations. The KCSE examinations play a crucial role in student's life since it determines progression to higher education, training and job placement. Therefore, it ignites public pressure on school administrators and teachers to improve students' academic performance. Among the principals, given the current emphasis on transformational leadership in the pursuit of increasing students' academic performance, there is clear need for the training, adoption and practice of individual consideration, intellectual stimulation, idealized influence and inspirational motivation transformational leadership style practices.

Bomet County has continued to experience disparity in the students' academic performance in secondary schools and few students are joining the universities. This could be attributed to a gap in the transformational leadership behaviours among the secondary principals. During the five years K.C.S.E. examinations from 2010 to 2014, the average range mean scores disparity of the academic performance were 6.20 points for county and 5.00 points for sub-county schools. The average mean score was 5.30; mean grade of C- for the four years from 2011 to 2014 K.C.S.E examinations. This was below average of mean grade $\mathrm{C}$, mean score of 6.00 .

In addition, the average academic Performance was below the minimum university entry score of mean grade C + in K.C.S.E examinations. In order to enhance understanding and suggest solutions to this problem, there was need to determine whether there were differences or absence of the idealized influence transformational leadership practices among some principals. Thus, there was a need to investigate the relationship between the transformational leadership and students' academic performance in KCSE.

\subsection{Purpose of the Study}

The purpose of the study was to determine the relationship between principals' transformational leadership style and secondary school students' academic performance in Bomet County, Kenya.

\subsection{Objective of the Study}

The study was guided by the following objective:

i) To establish the relationship between idealized influence of principal's transformational leadership style and students' academic performance in the secondary schools in Bomet County.

\subsection{Research Question}

The study sought to answer the following research question:

i) Is there relationship between idealized influence of principal's transformational leadership style and students' academic performance in the secondary schools in Bomet County?

\section{Theoretical Framework}

This study was based on Contingency Leadership 
Theory as expounded by Oyetunyi (2006) that there are diverse, complex situations in schools that demand diverse leadership skills. Our society was characterized by change, which also affects the school as the expectations of the stakeholders change from time to time. Chang'ach and Muricho (2013) affirm that education is a key to any nation's development and for it to play this role, education reforms should be inclusive. Ministry of Education (2012) policy framework for reforming education and training in Kenya enhances reforms stated in the Republic of Kenya Basic Education Act (2013) which advocates that basic education is a fundamental human right. Choge and Oruta (2015) assert that education policy faces a familiar public policy challenge in Kenya today: Local implementation was difficult. Kimani's et al., (2013) notes that instructional leadership paradigm was thought to have served the schools well.

Modern demands for educational reforms have made school leaders to look for an alternative. A recent theory that has been embraced by many school leaders is transformational leadership. Also Valmarie (2012) asserts that school principals' leadership is key to successful school reform, as it increase student achievement. And KESI (2011) adds that strategic thinking needs transformational leadership in order to efficiently and effectively implements developed strategic direction to achieve desired results. Also Marks and Printy (2003) confirms in their study that transformational leadership emerged as the model needed by principals to lead schools through reform. Anderson (n.d.) concluded that, educating, training and developing of school leaders should be geared towards application of the transformational leadership style. Leadership styles and approaches be explored in order to strengthen education leader ability to manage and lead schools in this new era is logical and necessary. As Cited by Jebii (2019), researchers in the recent past have established that transformational leadership is an effective leadership strategy that enables leaders to guide followers to successfully implement change within their organizations (Hassan \& Hatmaker, 2014).

Hence, the theory suited the study since the transformational leadership style was a vehicle through which the national educational reforms can be implemented at school level in Kenya. According to (www.learn-to-be-leader.com) transformational leadership is all about change. Murray (2014) affirms that it involves change. The change orientation is towards the greater good and positive. Stewart (2006) concludes, it is necessary to collectively determine the purpose of school leadership and make changes in our school systems that positively impact student learning. Onorato (2013) asserts, in this ever-changing era of accountability and performance, we find school leaders are now faced with same managerial tasks that are practised by managers and businesses in private industry.
Cheserek and Mugalavai (2012) points, Kenya is faced with many challenges that require urgent reforms to be able sustain the ever increasing demand for education. School needs to bring important reforms which are directly linked with teaching and learning processes. Alam (2017) concluded that there is need to revisit the traditional approaches of leadership and align it towards more productive lines. This necessitates a study that would bring out to the fore the best leadership practices that can improve secondary school students' learning outcomes. According to the studies, strengthening transformational leadership leads to the improvement of learning outcomes. In this study, the principal's transformational leadership practices came into focus. The transformational leadership practice had influence on student academic achievement in KCSE examinations. Thus, if the principals apply could improve academic performance bridging the academic achievement gaps among the schools.

\section{Research Methodology}

The study adopted descriptive survey design. Mugenda and Mugenda (1999) asserts that descriptive survey research design describes existing phenomena by asking individuals about their perceptions, attitudes, behaviour or values and can be used for exploring the existing status of two or more variables, at a given point. The design was chosen because it was suitable to the study since it involved describing and exploring the relationship of principals' transformational leadership styles and students' academic performance in Bomet County.

The population is an entire group of individuals, events or objects having common observable characteristics (Mugenda \& Mugenda, 1999). The population of the study included the Director of Studies and Quality Assurance and Standards Officers. There were 130 Directors of Studies based on 130 public secondary schools which had candidates from 2010 to 2014 K.C.S.E. examination in Bomet County and five Quality Assurance and Standards Officers in Bomet County having five sub-counties. Out of the 130 public secondary schools, 16, 17 and 97 are boys', girls' and mixed public secondary schools respectively, both day and boarding.

To determine the sample size of the study, Slovin's formula with 95\% confidence level was used. From using the formula, a sample of 15 boys', 15 girls' and 78 mixed public secondary schools making 108 public secondary schools in total were selected from the 130 public secondary schools in Bomet County. From each school selected, a Director of Studies was chosen.

The 108 Directors of Studies and five Quality Assurance and Standards Officers in Bomet County from the five subcounties were purposively sampled. Therefore the total respondents were 108 Directors of studies and five Quality 
Assurance and Standards Officers, totalling 113. Hence, were 83.7 percent sampled. The respondents were chosen because the Directors of Studies and Quality Assurance and Standards Officers have pertinent facts on principal's leadership style and academic issues in schools.

The Slovin's formula is shown below:

$$
\mathrm{n}=\mathrm{N} /\left(1+\mathrm{Ne}^{2}\right)
$$

Where:

$\mathrm{n}=$ Number of samples,

$\mathrm{N}=$ Total population

$\mathrm{e}=$ Error tolerance

Source: Horse (2015)

In order to select 108 Directors of studies and five Quality Assurance and Standards Officers: stratified random and purposive sampling procedures were used. The stratified random sampling was used to sample out the schools as follows: 15 Boys', 15 Girls' schools and 78 mixed schools. Mugenda and Mugenda (1999) states, the goal of stratified random sampling is to achieve desired representation from various subgroups in the population. It can reduce sampling error, while cluster sampling increases it for the same sample size (Moore, 2016). Then purposive sampling was employed to select Directors of studies and also the Quality Assurance and Standards Officers. This was because they have critical knowledge on school life.

The study used research instruments for data collection of three types: Questionnaires, interview guide and document analysis which were designed based on the objectives of the study. There were questionnaires for Director of Studies' questionnaires (DQ) and Quality Assurance and Standards Officers' interview guides (QASO1). School and County Director of Education KCSE records were examined to provide in-depth information on students' academic performance. It was useful in tracking down accurate academic performance trend in K.C.S.E. examination from the year 2010 to 2014. The K.C.S.E. records analyses were used. And revealed the gaps to be bridged in the study

Piloting of the instruments was done in 13 schools. Mugenda and Mugenda (1999) advised that the pretest sample is between $1 \%-10 \%$. The schools were sampled for the study using simple random sampling. Therefore 13 Directors of Studies were involved in piloting, hence were $10 \%$ sampled. The results from the piloted research instruments determined the reliability of the instruments.

To find out the internal consistency of the questionnaire, Cronbach's coefficient Alpha which is a general form of the Kunder-Richardson (K-R) 20 formula, was employed.

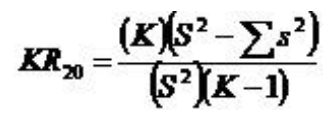

Where $\boldsymbol{K R}_{\mathbf{2 0}}=$ Reliability coefficient of internal consistency

$\boldsymbol{K}=$ No of items used to measure the concept

$\boldsymbol{S}^{2}=$ Variance of all scores

$\boldsymbol{s}^{\mathbf{2}}=$ Variance of individual items

Cronbach's coefficient Alpha is used to determine how items correlate among themselves. The results yielded Alpha of 0.81 . The result implies that the items correlated highly among them i.e. there was consistency among the items in measuring the concept of your interest (Mugenda $\&$ Mukenda, 2003). The inter-rater reliability was used to test the reliability of the interview guide and the percentage of agreement was $70 \%$. Therefore, the instruments were reliable and acceptable for the study.

\section{Results and Discussions}

The secondary schools' academic performance results shows that 50(94.3\%) were improving, while 3(5.7\%) were declining in the last three years from 2012 to 2014 K.C.S.E. examinations. Those schools with the improving trend in the KCSE results had an average mean score of 5.300, mean grade of C-. Respectively those with declining trend had average mean score of 4.100, mean grade of D+ over the last three years. Then relationship between the idealized influence transformational leadership practice and secondary school students' academic performance was determined. A cross tabulation of the academic performance in KCSE was developed to facilitate a Chi square test analysis. The results of the extent of principals' idealized influence are presented in the Table 1.

Table 1 show, 42 (79.3\%) of the sampled Directors of Studies' responses indicate they agreed that the principals' leadership displayed an idealized influence, while 5(9.4\%) disagreed and $6(11.3 \%)$ not sure. Based on the cross tabulation analysis, their responses on academic performance in KCSE improving trend were: 2 (3.8\%), $8(15.1 \%)$ and $40(75.5 \%)$ disagree, neutral and agree respectively. Respectively on the declining trend were: 1 $(1.9 \%), 0(0.00 \%)$ and $2(3.8 \%)$ (Table 2). In order to determine the association between idealized influence of principals' leadership and students' academic performance in KCSE, the study applied Chi square test. The findings are indicated in Table 2. 
Table 1. Director of Studies' Responses on Idealized Influence of Principals' Leadership

\begin{tabular}{|c|c|c|c|c|c|}
\hline \multirow{2}{*}{ Statement } & & & & & \\
\hline & & $\mathbf{D}$ & $\mathbf{N}$ & $\mathbf{A}$ & Total \\
\hline \multirow{2}{*}{ The principal sets an example by working hard himself/herself } & $f$ & 4 & 6 & 43 & 53 \\
\hline & $\%$ & 7.5 & 11.3 & 81.2 & 100.0 \\
\hline \multirow{2}{*}{ The principal coaches and mentors teachers } & $f$ & 7 & 9 & 36 & 53 \\
\hline & $\%$ & 13.2 & 17.0 & 67.8 & 100.0 \\
\hline \multirow{2}{*}{ Information on Idealized Influence of Principals' } & $f$ & 5 & 6 & 42 & 53 \\
\hline & $\%$ & 9.4 & 11.3 & 79.3 & 100.0 \\
\hline
\end{tabular}

Table 2. Director of Studies' Responses on Idealized Influence of Principals' Leadership and Students' Academic Performance in KCSE

\begin{tabular}{|c|c|c|c|c|c|c|}
\hline & & & \multicolumn{3}{|c|}{ Idealized Influence of Principals' Leadership } & \multirow{2}{*}{ Total } \\
\hline & & & Disagree & Neutral & Agree & \\
\hline \multirow{4}{*}{ Students' Academic performance } & \multirow{2}{*}{ Improving } & $\mathrm{f}$ & 2 & 8 & 40 & 50 \\
\hline & & $\%$ & 3.8 & 15.1 & 75.5 & 94.3 \\
\hline & \multirow{2}{*}{ Declining } & $\mathrm{f}$ & 1 & 2 & 0 & 3 \\
\hline & & $\%$ & 1.9 & 3.8 & 0.0 & 5.7 \\
\hline \multirow{2}{*}{\multicolumn{2}{|c|}{ Total }} & $\mathrm{f}$ & 3 & 10 & 40 & 53 \\
\hline & & $\%$ & 5.7 & 18.9 & 75.5 & 100.0 \\
\hline \multicolumn{7}{|c|}{ Chi-square $\left(\chi^{2}\right)$} \\
\hline
\end{tabular}

From Table 2 above, the Chi square value $=10.553$, d. f. $=2$, Significance value $(\mathrm{p}-$ value $),=0.005$. Hence, there was statistical significant relationship since the $\mathrm{p}-$ value was less than the level of significance (0.05). This means the principals' idealized influence was associated with students' academic performance in KCSE. The decline or improvement trend of the academic performance was contributed by the principals' idealized influence. Hence, it can be deduced that idealized influence could bridge the students' achievement gap and low academic achievement in KCSE in Bomet County. A principal who exhibits idealized influence attributes are likely to cause improved students' academic achievement in KCSE. Therefore, principals should focus efforts on those behaviours and activities that foster idealized influence such as being a role model, coaching and mentoring teachers. Hence, the principals experiencing a downward trend in the KCSE performance are advised to adopt the idealized influence attributes to turn around the performance trend. This finding agrees with Balyer (2012) that principals demonstrate idealized influence behaviours highly in school. And with Fraih (2014) that idealized influence directly and indirectly influence student achievement.

\section{Conclusions}

There was a statistical significant relationship in idealized influence dimension of principals' transformational leadership style as perceived by director of studies and secondary students' academic performance in KCSE in Bomet County. It is highly associated with the students' academic performance. Hence, idealized influence could bridge the students' achievement gap and low academic achievement in KCSE in Bomet County. A principal who exhibits idealized influence attributes are likely to cause improved students' academic achievement in KCSE. Principals experiencing a downward trend in the KCSE performance are advised to adopt the idealized influence attributes to turn around the performance trend.

\subsection{Recommendation}

The objective of this study was to establish the relationship between idealized influence of principal's transformational leadership style and students' academic performance in the secondary schools in Bomet County. Based on the findings of the study, the following recommendation was made:

i. Principals should focus on those characteristics that foster idealized influence such as being a role model, coaching and mentoring teachers. Their intensified adoption and use of idealized influence dimensions of transformational leadership styles by principals enhances academic performance in KCSE examinations.

\section{REFERENCES}

[1] Achieng, N., B. (2013). Teachers' And Students' 
Perceptions Of Principals' Transformational Leadership And Students' Academic Achievement In Public Secondary Schools of Nairobi County, Kenya. Doctor of Philosophy Degree, The Catholic University of Eastern Africa

[2] Adepoju, T. L., Oluchukwu, E. E. (2011). A study of secondary school students' academic Performance at the senior school certificate examinations and implications for educational planning and policy in Nigeria. An International Multidisciplinary Journal, 5 (6), 314-333. DOI: http://dx.doi.org/10.4314/afrrev.v5i6.26

[3] Alam, S.(2017). A study on leadership styles executed by principal and academic coordinator in one of the private schools in Gilgit Baltistan, Pakistan. Academic Research International, 8(3) 71-78.

[4] Anderson, M. (N.D.) "Transformational Leadership in Education: A Review of Existing Literature. International Social Science Review: 93(1), 1-15.

[5] Awino,J., Kiplangat, R. K. and Onderi, H. (2014). Factors Contributing To Poor Academic Performance in Kenya Certificate of Secondary Education In Public Secondary Schools in Kericho Sub - County, Kericho County, Kenya Kenya Journal of Educational Planning, Economics \& Management 7 (2), 2074 -5400

[6] Balyer, A. (2012). Transformational leadership behaviours of school principals: A research based on teachers' perceptions. International On line Journal of Educational Sciences, 4(3), 581-591. Retrieved April 29, 2013, from www.ioje.net

[7] Bidwell, A. (2013). American students fall international academic test, Chinese lead the pack. Retrieved from www.usnews.com/news/articles/2013/1...

[8] Cashin, J. (2000). Transformational leadership. Retrieved 26.5.2016 from https://www.mun.ca

[9] Chang'ach, J. K. \& Muricho, W. P. (2013). Education Reforms in Kenya For Innovation. International Journal of Humanities and Social Science, 3(9), 123-142 June 2, 2013, from www.ascd.org/...

[10] Choge, J. R. (2015). Gender factor in decision making: challenges facing women leadership In development in primary schools management in Kenya. Journal of Education and Practice, 6(12), 30-36. Doi: 222-288X

[11] Choge, J. R. \& Oruta F. (2015). Policy Formulation and Implementation in Education in Kenya: Re-framing the Missing Link.Kabarak University 5th Annual International Conference 14th - 17th July 2015

[12] Cooper, G., J. (2011). The influence of school variables on the principals' instructional Leadership style in elementary schools in an urban setting. Abstract, Thesis, Chapel Hill, The University of North Carolina. Doi: 3465188.

[13] Denmark, V. (2012). Transformational Leadership- A Matter of Perspective. Retrieved from http://www.advac-e d.org/source/transformational-leadership-a-matter-of-persp ective

[14] Fraih, A. (2014). The role of transformational leadership in influencing students' outcomes in public secondary schools in Kuwait. Brunel University London. Retrieved from http://bura.brunel.ac.uk/handle/2438/10684
[15] Germano, M. O. (2010, June 6). Leadership Style and Organizational Impact. Spotlight Newsletter

[16] Hauserman, C. P. \& Stick, S. L. (2013). The leadership teachers want from principals. Transformational Canandian Journal of Education, 36(3), 185-197

[17] Horse, T. (2015). How to use Slovin's formula. Retrieved from http://www.statisticshowto.com/how-to-use-slovins-f ormula/

[18] Hughes, T. A. (2014). Idealized, Inspirational, and Intellectual Leaders in the Social Sector: Transformational Leadership and the Kravis Prize, Ph.D. Thesis, Claremont Mckenna College.

[19] Jess, C. (2014). Transformational leadership: the most effective leadership style? Retrieved 26.5.2016 from https://www.wattsnext.com.au

[20] Kaimenyi, J. T. (2014). 2014 Basic Education Statistical Booklet. Ministry of Education

[21] KEMI (2014). Diploma in Education Management, Transforming Education Management, Module 2, Distance Learning Course. Nairobi, KEMI

[22] Kenya National statistics Bureau (2017). Economic Survey, Government printers.

[23] KESI (2011). Diploma in Education Management for Secondary Schools: Distance Learning Course. Nairobi, Kenya Literature Bureau.

[24] Khademfar, M. \& Idris, K. (2012). The Relationship between Transformational Leadership and Organizational Health in Golestan Province of Iran. International Journal of Humanities and Social Science, Special Issue, 2, 218.

[25] Kigotho, W. (2011). Principal of the Year-2009. Teachers' IMAGE Magazine, 17, 31-39.

[26] Kimiti, R. P. \& Mwinzi, K. A. (2016). Impact of Transformational Leadership Style on Secondary School Students' Academic Performance. Internal Journal of Education and Research, 4(7), 1-18

[27] Kinyua, J. M. (2015). Factors That Influence Principals' Managerial Effectiveness in Secondary Schools in Nakuru Municipality, Kenya. Kabarak University 5th Annual International Conference 14th - 17th July 2015

[28] Koskei, C. A., Tanui, E \& Rono, R. (2018). Influence of selected leadership styles of principals on performance of public secondary schools in Narok South, Kenya. International Journal of Science and Education Research, 2(1)

[29] Makau, N. N. \& Tanui, E. K. (2014). Relationship between Instructional Leaders' Gender and Student's Academic Achievement in Sciences and Mathematics. US Open Educational Research Journal, 1(2), 1-17

[30] Marks, M. \& Printy, S. (2003). Principal leadership and school performance: an integration of transformational and instructional leadership. Educational Administration Quarterly, 39 (3), 370-397.

[31] Ministry of Education (2014).Education for All 2015 National Review. Nairobi: Ministry of Education. 
[32] Ministry of Education (2012). A Policy Framework For Education And Training. Nairobi: Ministry of Education.

[33] MoEVT (2013). Report on Effective School Leadership and Quality Education in Zanzibar. Retrieved June 2013, from http://learning-report_tcm76-35043.pdf

[34] Moffit, J. R. (2007). What works: Principals leadership behaviours that positively impact Student achievement in elementary schools. Thesis, Georgia Southern University.

[35] Moore, T. (2016). What is the difference between stratified and cluster sampling? Retrieved 4.6.2016 from www.quora.com

[36] Mugenda, O. M. \& Mugenda, G. A. (1999). Research Method, quantitative Approaches. Nairobi: Acts Press.

[37] Murray, J. (2014). A Quide to Transformational Leadership. Retrieved from www.legacee.com

[38] Nowlin, D. (2015, April13). No Child Left Behind: An overview. Education Week

[39] Nderitu, A. W. (2012). Effects of Principal Transformational Leadership Characteristics on Students Academic Performance in Secondary Schools in Nairobi County Kenya. American Journal of Educational Research, 2 (9), 801-810 Retrieved March, 21st, 2015, From httpts://profiles.uonbi.ac.ke/anne-nderitu/.../ DOI: 10.12691/education-2-9-15

[40] Nderitu, A. W., Kimani, D. G., Nyagah, D. G. \& Gikonyo, N. (2013). Transformational Leadership Practices of School Principals: Does School Ownership Matter?In: Second Annual International Interdisciplinary Conference. Catholic University of Eastern Africa (CUEA), Retrieved March, 21st, 2015, From Dr. Anne Wairimu Nderitu Website httpts://profiles.uonbi.ac.ke/anne-nderitu/.../

[41] Nderitu, A. W., Kimani, D. G., Kidombo, H. and Gikonyo, N. et al (2013). Transformational Leadership of skills: recipe for school pricipals in the 21st centuary. Retrieved March, 21st, 2015, From Dr. Anne Wairimu Nderitu Website httpts://profiles.uonbi.ac.ke /anne-nderitu/.../

[42] Nderitu, Gikonyo and Kimani (2014). Inspiring a Shared Vision: Getting All The Teachers in the Bandwagon. Journal of Education and Practice, 5(5), 1-6.

[43] Nderitu, A. W., Kimani, D. G., \& Gikonyo, N. (2015). Preaching and drinking wine: A neccessity for transformational leaders in effective schools. International Journal for Education Research, 3(3), 2-7. Doi: 2201-6740.

[44] Ndiga, B. , Mumuikha, C. , Flora, F. , Ngugi, M. , \& Mwalwa, S. (2014). Principals' Transformational Leadership Skills in Public Secondary Schools: A Case of Teachers' and Students' Perceptions and Academic Achievement in Nairobi County, Kenya. American Journal of Educational Research, 2(9), 801-810.

[45] Nkaiwuatei, J.K.O (2013). An analysis of critical factors affecting academic performance in Secondary Education in Kenya. A case of Narok North District Project, Moi University.

[46] Nsubuga, Y.K., (2008) Analysis of Leadership Styles and School Performance of Secondary Schools in Uganda. PhD Thesis, Nelson Mandela Metropolitan University
[47] Nyagosia, P. O (2011). Determinants of Differential Kenya Certificate of Secondary Education Performance and School Effectiveness In Kiambu and Nyeri Counties, Kenya. Master's Thesis, Kenyatta University.

[48] Nyongesa, L. P. (2014). Head Teachers Leadership Style on School Academic Performance in Kenyan Secondary School. Masters Research Project, University of Nairobi.

[49] Ogalo, E. A. (2013). Influence Of Principals' Leadership Styles on Students Achievement in KCSE of Secondary Education in Awedo District, Kenya. Master' Project, University of Nairobi

[50] Oyetunji, C. O. (2006). The Relationship Between Leadership Style and School Climate in Botswana Secondary Schools. PhD thesis, University of South Africa.

[51] Republic of Kenya (2013). Basic Education Act. Nairobi: Government Printer.

[52] Robinson, V. J. M, Lloyd, C. A., \& Rowe, K. J. (2008). The Impact of Leadership on Student Outcomes: An Analysis of the Differential Effects of Leadership Types. Educational Administration Quarterly, 44(5), 635-674. DOI: 10.1177/ 0013161X08321509

[53] Stewart, J. (2006). Transformation al Leadership: An Evolving Concept Examined Through the Works of Burns, Bass, Avolio, and Leithwood. Canaadian Journal of Educational Administration and Policy, 54. Retrieved from https//www.

[54] Valmarie, R. (2012). The Examination Of The Relationship Among Secondary Principals' Leadership Behaviours, School Climate And Student Achievementin Urban Context. Retrieved from http:digital.fiu.edu/etd/635

[55] Veysel, O. (2014). Relation between secondary school administrators' transformational and transactional leadership style and skills to diversity management in school. Theory and Practice, 14(6),2162-2174. Doi: 10.12738/estp.2014.6.2128 